Jurnal Pemberdayaan: Publikasi Hasil Pengabdian kepada Masyarakat

Vol. 2, No. 2, Agustus 2018, Hal. 325-332

ISSN: 2088 4559; e-ISSN: XXXX-XXXX

DOI:

\title{
UPAYA PENINGKATAN KELUARGA SAMARA DI PUNDONG BANTUL, YOGYAKARTA
}

\author{
Tri Wahyuni Sukesi ${ }^{1}$, Adam Abdul Malik ${ }^{1}$, Siska Handayani ${ }^{1}$ \\ Universitas Ahmad Dahlan, Yogyakarta \\ Email: yunisukesi.fkmuad@gmail.com
}

\begin{abstract}
ABSTRAK
Keluarga sakinah mawadah warohmah (Samara) adalah keluarga yang sejahtera dan penuh dengan kasih sayang di dalamnya. Tantangan untuk bisa menuju keluarga Samara ini tidak sedikit sehingga setiap keluarga harus disiapkan untuk bisa menuju keluarga samara. Tujuan dilakukan pengabdian masyarakat ini adalah untuk meningkatkan kesiapan keluarga dalam upaya menuju keluarga yang samara. Metode yang dilakukan adalah dengan penyuluhan, pelatihan dan pendampingan selama mahasiswa melakukan KKN. Hasil yang diperoleh adalah kegiatan penyuluhan, pelatihan dan pendampingan dapat berjalan dengan lancar. Masyarakat dapat bekerjasama dengan baik sehingga semua kegiatan dapat dilakukan bersama sama. Akibat dari kegiatan ini masyarakat khususnya yang sudah berkeluarga dan yang akan berkeluarga memiliki pemahaman tentang keluarga Samara dan upaya-upaya yang dapat dilakukan untuk mencapai keluarga Samara tersebut.
\end{abstract}

Kata kunci: keluarga, SAMARA, upaya

\begin{abstract}
The sakinah mawadah warohmah (Samara) family is a family that is prosperous and full of affection in it. The challenge of being able to get to the Samara family is so much that each family must be prepared to be able to go to the samara family. The purpose of implementing this service activity is to increase family preparedness in an effort to reach the same family. The method used is counseling, training and mentoring as long as students do $K K N$. The results obtained are counseling, training and mentoring activities can run smoothly. The community can cooperate well so that all activities can be carried out together. As a result of this activity the community, especially those who are married and who will have a family, have an understanding of the Samara family and efforts that can be made to reach the Samara family)
\end{abstract}

Keywords: family, SAMARA, effort 


\section{PENDAHULUAN}

Keluarga adalah kelompok masyarakat terkecil, yang dibentuk antara laki laki dan perempuan yang telah melakukan ikatan resmi secara agama dan hukum negara. Di dalam keluarga akan terjadi suatu interaksi, komunikasi dan kerjasama antar anggota keluarga lainnya (Hyoscyamina, 2011). Kehidupan keluarga merupakan suatu perjalanan kehidupan yang kadang sulit dan kadang juga mudah. Setiap keluarga diharapkan akan selalu dalam keadaan stabil dan baik. Hampir setiap orang yang akan membentuk suatu keluarga baru selalu berharap akan menjadi keluarga yang sakinah mawaddah dan marohmah (Samara) (Priyadi et al., 2013).

Keluarga sakinah berarti adalah keluarga yang penuh dengan ketenangan, kedamaian, ketenteraman. Mawadah artinya 'kasih sayang, upaya untuk selalu melindungi dan menjaga orang orang yang disayangi dari hal hal yang tidak baik'. Warohmah artinya 'kelembutan hati sehingga akan saling berbuat baik dengan pasangannya'. Keluarga yang Samara berarti keluarga yang damai, penuh kasih sayang dan penuh dengan rahmat dan kesejahteraan (Ismatulloh, 2015).

Permasalahan yang diangkat adalah masalah peningkatan keluarga Samara yang tidak saja hanya keluarga samara secara agama tetapi juga secara ekonomi, kesehatan, dan pendidikan. Kegiatab ini dilakukan di Kecamatan Pundong yang memang fokus terhadap ketahanan keluarga khususnya dalam mewujudkan keluarga yang sakinah, mawadah dan warohmah. Banyaknya permasalahan yang dihadapi dalam kehidupan keluarga dan berbagai macam tuntutan seperti ketersediaan sandang, pangan, dan papan dapat menjadi faktor pemicu retaknya kehidupan suatu keluarga. Saat ini faktor luar yang menjadi tuntutan yang harus dipenuhi oleh suatu keluarga semakin banyak. Hal ini apabila tidak dikelola dengan baik oleh suatu keluarga maka akan menjadi hal yang tidak baik dalam kehidupan keluarga tersebut. Tingginya pernikahan dini di mana usia anak-anak terpaksa harus sudah membentuk keluarga sendiri tanpa ada persiapan apapun menyebabkan banyak keluarga baru ini menjadi rapuh dan mudah goyah akibat ketidaksiapan masing-masing menghadapi berbagai permasalahan keluarga (Aniqotsunainy and Paramytha, 2016).

Berbagai upaya yang dapat dilakukan untuk mewujudkan keluarga Samara adalah dengan berbagai macam dukungan di bidang pendidikan, ekonomi, kesehatan, sosial budaya dan agama. Peningkatan pengetahuan tentang keluarga Samara dan upaya-upaya yang bisa dilakukan untuk mewujudkan keluarga samara kepada keluarga baru. Penguatan keluarga dengan memberikan pelatihan-pelatihan di bidang ekonomi dan kewirausahaan agar keluarga 
mampu berdaya di bidang ekonomi dan memenuhi kebutuhan ekonominya sehingga keluarga menjadi sejahtera dan tidak kekurangan dalam memenuhi kebutuhan pokoknya. Di bidang agama dengan melakukan kajian kajian menurut agama masing-masing untuk menjadi penguat keluarga dari sisi agama dan rohani. Penguatan secara psikologis dengan adanya kegiatan parenting dan penyuluhan-penyuluhan psikologi keluarga. Hal tersebut merupakan berbagai macam upaya yang dapat dilakukan untuk menguatkan suatu keluarga (Setiadi, 2017).

\section{METODE}

Metode yang dilakukan dalam kegiatan ini adalah penyuluhan, pelatihan, dan pendampingan selama mahasiswa melakukan KKN.

\section{HASIL, PEMBAHASAN, DAN DAMPAK}

Kegiatan yang dilakukan dalam upaya peningkatan keluarga Samara di Kecamatan Pundong dilakukan dengan melakukan beberapa kegiatan yang berjalan dengan baik semuanya dan masyarakat antusias dalam mengikuti rangkaian kegiatan baik pada kegiatan inti penyuluhan maupun pada kegiatan monitoring evaluasi kegiatan.

Kegiatan yang dilakukan dalam upaya peningkatan keluarga samara di Pundong adalah pertama adalah pembuatan dan Pemasangan sticker Samara. Kegiatan ini bertujuan untuk sosialisasi tentang keluarga Samara pada masyarakat. Pada stiker tersebut ditulis kata yang berhubungan dengan keluarga Samara. Hal ini diharapkan dapat terus diingat oleh warga terkait keluarga samara dan apabila sering dibaca maka akan menjadi hal yang bisa mempengaruhi pemikiran seseorang.

Pelatihan menciptakan jiwa usaha. Jiwa usaha haruslah dimiliki oleh setiap orang. Hal ini untuk membantu perekonomian masyarakat. Maka dari itu, program menciptakan jiwa usaha ini dirancang untuk membantu masyarakat dalam menciptakan jiwa usaha untuk kemudian mampu menjadi usahawan. Hal ini merupakan pendukung terwujudnya keluarga Samara dari sektor ekonomi. Ekonomi memiliki peran yang sangat penting dalam kehidupan berkeluarga. Segala kebutuhan pokok keluarga seperti sandang, pangan, papan, pendidikan dan kesehatan semua dapat terpenuhi apabila keluarga memiliki perekonomian yang baik. Apabila dalam suatu keluarga tidak ada yang bertugas mencari nafkah maka kebutuhan tersebut tidak dapat terpenuhi dengan baik. Saat kebutuhan ekonomi tidak terpenuhi dengan baik dapat menjadi pemicu permasalahan keluarga. Kegiatan ini diikuti oleh ibu-ibu rumah 
tangga, harapannya hal ini dapat dilakukan oleh ibu-ibu rumah tangga untuk membantu menambah pemasukan untuk keluarga.

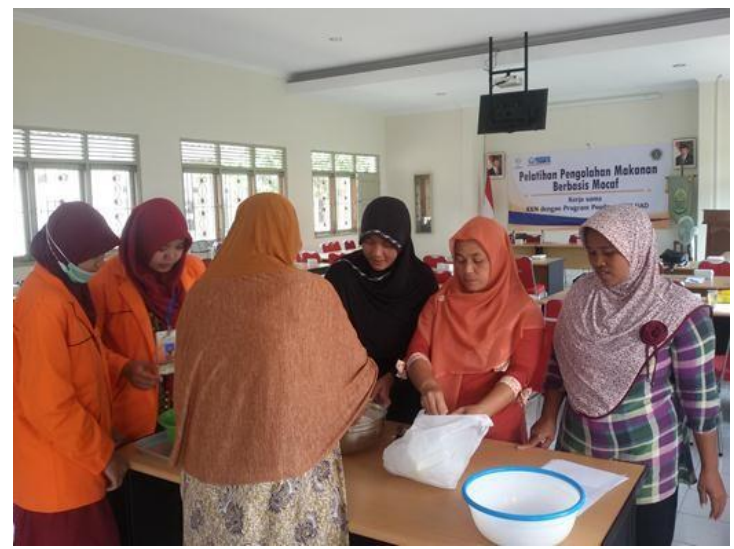

Gambar 1. Pelatihan Pembuatan Mocaf

Penyuluhan pemahaman sejak dini pentingnya menabung. Kegiatan ini bertujuan untuk menumbuhkan jiwa hemat pada anak sejak dini. Hal ini dapat membantu untuk mengurangi pengeluaran keluarga untuk hal-hal yang tidak terlalu penting sehingga keuangan keluarga dapat diatur dengan lebih baik. Pelatihan diikuti oleh anak anak dan kegiatan dilakukan dengan menyenangkan sehingga anak-anak dapat mengikuti dengan gembira dan ceria.

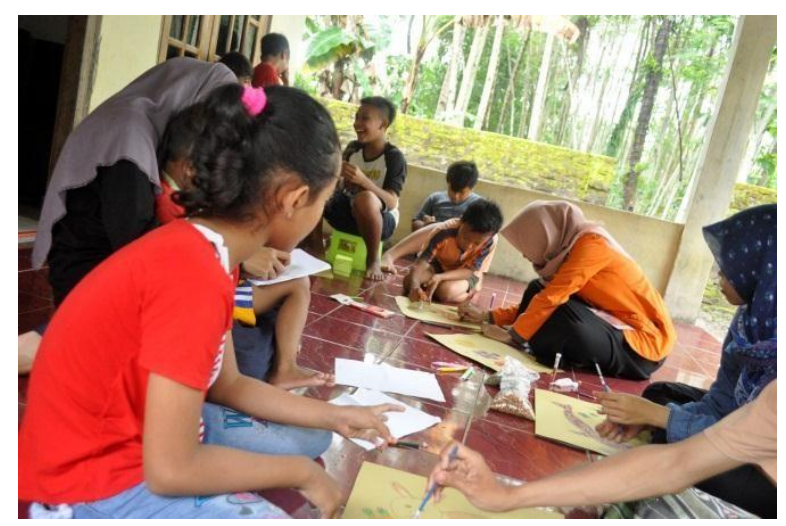

Gambar 2. Pelatihan Gemar Menabung dengan cara yang Menyenangkan

Penyuluhan makanan empat sehat lima sempurna bertujuan untuk memberikan pemahaman tentang pentingnya menjaga kesehatan keluarga dengan memperhatikan makanan sehari-hari. Penyuluhan TOGA bertujuan untuk mengenalkan pada masyarakat tentang tanaman obat yang selama ini ada di sekitar. Diharapkan, masyarakat dapat memanfaatkan tanaman tersebut sebagai obat. Kesehatan adalah hal yang sangat berharga, 
segala hal tidak akan mungkin dilakukan dengan baik apabila kondisi kesehatan juga tidak baik, sehingga kesehatan keluarga adalah pendukung terwujudnya keluarga Samara.

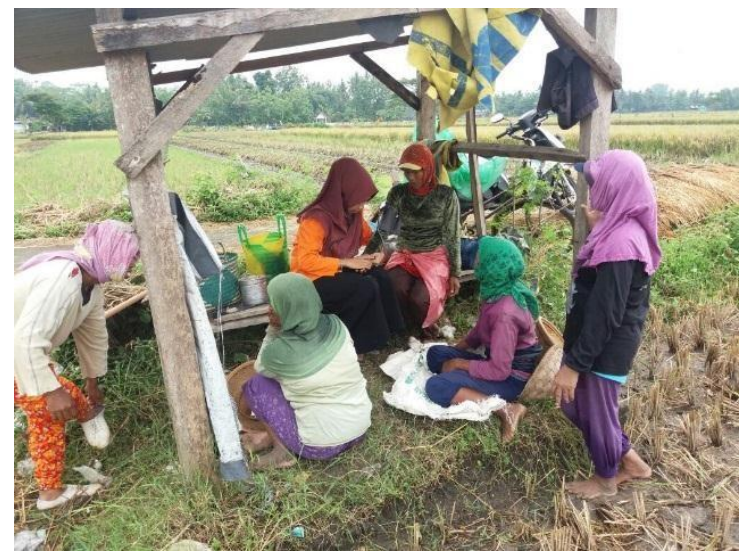

Gambar 3. Pelatihan Dan Pemeriksaan Kesehatan

Kegiatan yang selanjutnya adalah pengadaan poster 'posisi imam dan makmum dalam sholat'. Poster ini diadakan dengan tujuan untuk memberikan informasi yang tepat pada masyarakat tentang posisi imam dan makmum dalam sholat. Penyelenggaraan film animasi edukasi, Menonton film adalah hal yang menyenangkan bagi anak. Video menjadi media pembelajaran yang disenangi anak sehingga program ini bertujuan untuk memberikan edukasi pada anak melalui video. Penyelenggaraan games edukasi yang bertujuan untuk mengasah kemampuan anak dalam memahami dan mengenal materi pelajaran. Penyelenggaraan kebersihan kuku yang merupakan hal penting dalam menjaga kesehatan. Maka, hal ini dilaksanakan dengan tujuan untuk menumbuhkan hidup sehat pada anak. Penyelenggaraan pelatihan paduan suara yang bertujuan untuk melatih anak dalam pentingnya kerjasama dalam bernyanyi. Selain itu juga untuk melatih vokal dalam paduan suara. Penyuluhan dan pelatihan komunikasi efektif Kegiatan ini bertujuan untuk melatih anak dalam berkomunikasi secara efektif. Hal ini dimaksudkan supaya anak mampu berkomunikasi secara efektif di masyarakat. Pelatihan kerjasama tim dimaksudkan untuk menumbuhkan rasa percaya pada orang lain sehingga menumbuhkan jiwa sosial anak. Penomoran kepala keluarga melalui SAMARA bertujuan untuk pendataan jumlah rumah di dusun Badan. Selain itu juga untuk melaksanakan sosialisasi tentang keluarga SAMARA. Pembuatan dan pemasangan stiker dan poster anti narkoba Kegiatan ini bertujuan untuk mencegah penyebaran dan penggunaan narkoba di kalangan masyarakat dusun Badan. Terakhir adalah penyelenggaraan game tanya jawab. Game tanya jawab bertujuan untuk mengasah kemampuan anak dalam materi tertentu. Selain itu juga untuk mengasah kemampuan anak dalam kecepatan dan ketepatan pada pelaksanaan game. 


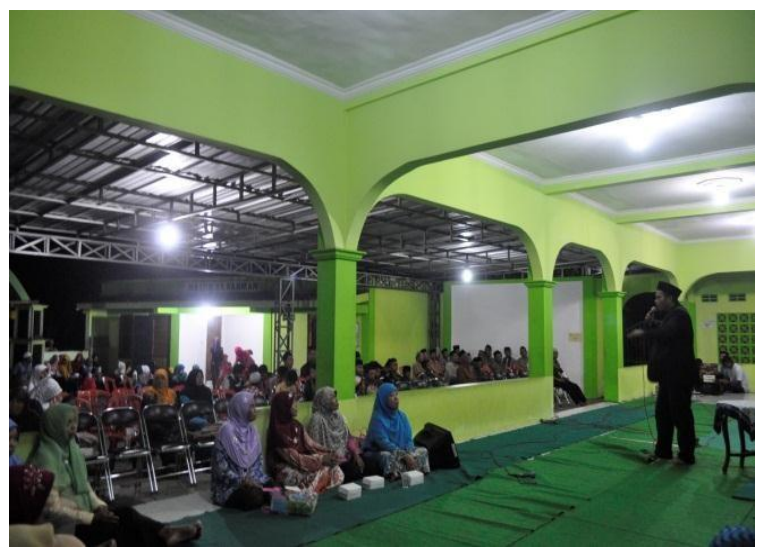

Gambar 4. Penyuluhan Tentang Keluarga Samara

\section{SIMPULAN}

Kegiatan pengabdian kepada masyarakat dalam rangka meningkatkan keluarga Samara di Kecamatan Pundong berjalan dengan sangat baik dan lancar. Peserta antusias baik dalam acara inti maupun dalam kegiatan monitoring evaluasi. Rangkaian kegiatan semua dapat berjalan dengan baik dan kerjasama dengan masyarakat juga terjalin dengan baik.

\section{DAFTAR PUSTAKA}

Aniqotsunainy, D. and Paramytha, N. (2016) 'Penguatan Keluarga Sakinah Bagi Ibu Muda di Kecamatan Umbulharjo Kota Yogyakarta', Jurnal Komunikasi dan Pendidikan Islam, 5 (1), pp. 21-52.

Hyoscyamina, D. (2011) 'Peran keluarga dalam membangun karakter anak', Jurnal psikologi Undip, 10 (2), pp. 144-152.

Ismatulloh, A. . (2015) 'Konsep Sakinah, Mawaddah dan Rahmah dalam Al-Qur'an (Prespektif Penafsiran Kitab Al-Qur'an dan Tafsirnya', Jurnah Mazahib Pemikiran Hukum Islam, XIV (1), pp. 47-48.

Priyadi, U., Adi, W., Hukama, R., Khinasih, A. and Susrianti, I. (2013) 'Penyuluhan keluarga sakinah, mawaddah, warahmah', Jurnal Inovasi dan Kewirausahaan, 2 (1), pp. 27-31.

Setiadi, T. (2017) 'Pembangunan Keluarga Sakinah Mawadah Warahmah Melalui Pembentukan Basis Keluarga Mandiri dan Peduli Menuju Masyarakat Sejahtera', Jurnal Pemberdayaan, 1 (1), pp. 72-78. 


\section{UCAPAN TERIMAKASIH}

Terima kasih diucapkan kepada:

1. Kecamatan Pundong Dusun Badan untuk kerjasama dan partisipasi yang baik

2. Universitas Ahmad Dahlan yang telah memberikan fasilitas untuk terlaksananya kegiatan ini 
